\title{
Effect of Imidocarb Application on Oxidative DNA Damage Caused by Anaplasmosis
}

\author{
Ahmet Cihat Öner ${ }^{1, a, *}$, Adnan Ayan ${ }^{2, b}$ \\ ${ }^{1}$ Department of Pharmacology and Toxicology, Faculty of Veterinary Medicine, Van Yüzüncü Yll Üniversitesi, 65040 Van, Turkey \\ ${ }^{2}$ Department of Genetics, Faculty of Veterinary Medicine, Van Yüzüncü Yıl Üniversitesi, 65040 Van, Turkey
}

*Corresponding author

\begin{tabular}{|c|c|}
\hline A R T I C L I N F O & A B S T R A C T \\
\hline $\begin{array}{l}\text { Keywords: } \\
\text { Anaplasmosis } \\
\text { Comet } \\
\text { DNA damage } \\
\text { Imidocarb } \\
\text { Treatment }\end{array}$ & $\begin{array}{l}\text { This study was aimed to evaluate DNA fragmentation by using Comet assay in naturally infected } \\
\text { sheep with Anaplasmosis before and after treatment with the Comet method, which shows DNA } \\
\text { damage specifically. In the study, blood samples were collected from } 10 \text { Anaplosmosis infected and } \\
10 \text { healthy sheep. The anaplosmosis was diagnosed by clinical signs and symptoms. The infection } \\
\text { was confirmed by Giemsa staining. The blood was collected from control group and infected group } \\
\text { before and after the treatment, from the vena jugularis with the appropriate method. The DNA } \\
\text { fragmentation was checked by using the Comet assay of blood cells. The data were analysed throught } \\
\text { ANNOVA one-way. The result showed higher DNA fragmentation in sick animals diagnosed with } \\
\text { anaplasmosis; tail length and tail moment values were found to be statistically significantly higher } \\
\text { than the control group. When the data obtained after imidocarb (IMD) application were compared } \\
\text { with obtained during the disease, a decreased DNA damage and tail moment was determined, } \\
\text { however, these values higher than control. In this study, DNA damage and the extent of this damage } \\
\text { were investigated by the Comet assay method using a healthy control group before and after treatment } \\
\text { in animals with Anaplasmosis. When the findings obtained from the study were evaluated, it was seen } \\
\text { that Anaplasma agents caused DNA damage and with the imidocarb application given for treatment, } \\
\text { DNA damage was reduced and results close to healthy individuals were obtained. }\end{array}$ \\
\hline
\end{tabular}

Türk Tarım - Gıda Bilim ve Teknoloji Dergisi, 9(12): 2308-2311, 2021

\section{Anaplazmosis ile Meydana Gelen Oksidatif DNA Hasarı üzerine İmidokarp Uygulamasının Etkisi}

\begin{tabular}{|c|c|}
\hline M A K A L E B İ L G İ S İ & Ö Z \\
\hline $\begin{array}{l}\text { Anahtar Kelimeler: } \\
\text { Anaplazmosis } \\
\text { Comet } \\
\text { DNA hasarı } \\
\text { İmidokarb } \\
\text { Tedavi }\end{array}$ & 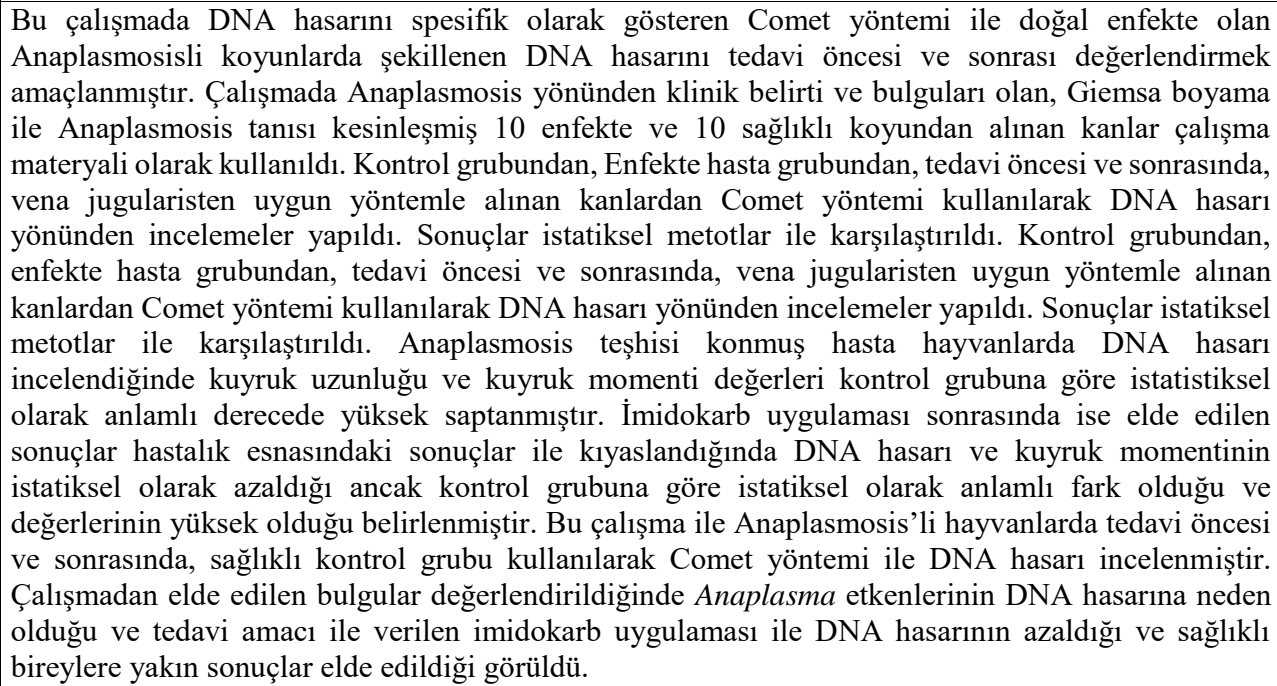 \\
\hline
\end{tabular}




\section{Introduction}

Anaplasmosis is an infectious disease that causes destruction in ruminant erythrocytes and is transmitted by ticks and blood-sucking arthropods. There are six Anaplasma species known to cause anaplasmosis: A. ovis, A. marginale, A. centrale, A. platys, A. bovis, and A. fagocytophilum. A. ovis and A. phagocytophilum are important factors causing anaplasmosis in sheep and goats. A. ovis causes more anaplasmosis in sheep and goats, especially in sheep (Shabana et al., 2018, Yang et al., 2018). Various tick species such as Rhipicephalus, Boophilus, Dermacentor, Ixodes, Ornithodurus belonging to the Ixoidea family play a role in the transmission of the disease. In addition, various Tabanus and Stomoxys species of stinging and bloodsucking flies and insects also play a role in mechanical transmission. In addition, iatrogenic contamination can be seen, such as the use of contaminated needles and instruments, dehorning, castration, and blood transfusion. It has been reported that transplacental transmission may occur rarely (Aktas et al., 2018, De Waal 2000).

In the case of Anaplasmosis, Anaplasma agents invade the erythrocytes, leading to hemolysis, resulting in anemia. In recent studies, it has been reported that oxidative stress is effective in the infection caused by Anaplasma species, the damage of erythrocytes and the formation of anemia (De et al., 2012; Jalali et al., 2016). Reactive oxygen radicals (ROS) are formed in cells and tissues by many different reactions. There are enzymatic (superoxide dismutase, catalase, etc.) and non-enzymatic (glutathione, vitamin, etc.) antioxidant defense systems that prevent the formation of reactive oxygen species and the damage caused by them (Değer et al., 2009; Esmaeilnejad et al., 2012). The balance between ROS and antioxidant systems must be maintained in the preservation of the structural integrity of cells and tissues and in their normal functioning. Disruption of this balance causes oxidative stress in the organism. Free radicals formed due to oxidative stress, on the other hand, cause damage to the basic structural elements of our body, such as proteins, lipids, carbohydrates and nucleic acids (Değer et al., 2009).

The erythrocyte membrane is very sensitive to lipid peroxidation, as it is rich in polyunsaturated fatty acids and is constantly exposed to high oxygen concentration (Jalali et al., 2016). In erythrocytes of animals infected with pyroplasmas such as Anaplasma and Theileria; The amount of free radicals that cause lipid peroxidation increases. Cell damage occurs due to this increase (Deger et al., 2009; Esmaeilnejad et al., 2012; Jalali et al., 2016).

DNA is a sensitive molecule and DNA damage can occur for various reasons. DNA damage leads to necrosis or cellular mutation when damage is high or repair systems are insufficient and this plays an important role in mutagenesis, carcinogenesis and aging (Kubota et al., 2005, Sardas 2005, Cemeli et al., 2009). Free radicals can attack any macromolecule, including DNA, and can cause lipid peroxidation, protein oxidation and DNA damage (Dinçer et al., 2009, Öner et al., 2020). DNA damage is characterized by structural damage such as disruption of chromatin structure, oxidation of DNA bases, mismatch and suppression of tubulin polymerization, chemical modification of bases, chromatin abnormalities, strand breakage, DNA-DNA and DNA-protein crossovers (Chen et al., 2002, Abdul Salam et al., 2016). Parasitic infections cause activation of inflammatory cells that play an important role in host defense. In addition, parasites increase the amount of free radicals in the tissues, organs and cells they inhabit and cause lipid peroxidation, which causes tissue and cell damage in the host. It has been reported that erythrocyte membrane fragility occurs as a result of increased lipid peroxidation and decreased antioxidant defense in the erythrocytes of animals with piroplasmosis (Chiou et al., 2012; Ince et al., 2010).

The Comet assay [single-cell gel electrophoresis (SCGE)], is a well-known method for the detection of DNA damage. This is a fast, simple, sensitive and widely used technique. While healthy DNAs do not form comets during transport, damaged DNAs move at different speeds in the electrical field, forming a tail-shaped image. DNA degradation, antioxidant status (resistance to $\mathrm{H} 2 \mathrm{O} 2$ degradation) and DNA repair levels in lymphocytes can also be measured with the comet assay (Collins 2004, Speit ve Hartmann 2006).

Many drugs have been advocated over the years as therapeutic or prophylactic agents against infection with hemoprotozoa in domestic animals. Among them, imidocarb (IMD) is considered the most efficacious and safest of all available medications (Kuttler, 1980). Imidocarb is a chemotherapeutic agent of the family of carbanilide derivatives [3, $3^{\prime}$-bis (2-imidazolin-2-yl)carbanilide] with antiprotozoal activity. It is usually administered as dipropionate salt and has been used for over $20 \mathrm{yr}$ in the treatment of some protozoal diseases such as babesiosis and Anaplasmosis in food-producing animals (Belloli et al., 2006, Kuttler, 1980).

Anaplasmosis is common worldwide, especially among small livestock, and causes serious economic losses. It has been reported that oxidative stress occurs in Anaplasma spp. infections, but studies showing precise DNA damage are insufficient in number. In this study, it was aimed to determine DNA damage in sheep naturally infected with Anaplasma spp. using the comet assay, which specifically shows DNA damage, and to evaluate the damage before and after imidocarb application.

\section{Materials and Methods}

\section{Sample Collection}

In this study, 10 mature Akkaraman sheep with a weight of 30-45 kg, aged 1-2 years, showing clinical Anaplasmosis symptoms, reared at a private farm located in district Van, Turkey was included as the patient group during the month of July 2021. The control group consisted of 10 healthy sheep, which were subject to the same region and rearing conditions, had no disease history and clinical findings specific to Anaplasmosis and other diseases, and were found to be negative for other blood parasites with laboratory evaluations. The blood samples were collected from all sheep under study. The blood samples were collected before and after the treatment (until day 10 after treatment), for laboratory analysis. All animals were kept in their natural habitat for the duration of the study. The study was performed with the Van YYU Animal 
Experiments Local Ethics Committee (VAN YUHADYEK) decision (It was decided that ethics committee approval was not required) (Approval no: 2020/12-07, date: 31.12.2020).

\section{Microscopic Diagnosis of Anaplasma spp.}

Blood smears prepared from animals were fixed with absolute methanol for five minutes and stained with 5\% Giemsa stain for 30 minutes. The slides were screened under oil immersion $(\times 100$ magnification) for the presence of Anaplasma-like bodies. If an agent has been found; the sample has been evaluated as positive.

\section{DNA Damage Analysis}

The Comet analysis method was used to determine DNA damage. It was applied on gel-coated slides according to the Comet protocol and spread was achieved. Prepared slides were run by the electrophoresis method (Boutet-Robinet et al., 2013). Prepared slides were determined using a fluorescence microscope (Oxion Microscopy for Fluorescence, The Netherlands) to examine DNA damage and the tail moment it produced. Subsequently, 6 images were taken to constitute the entire region of the slides. The \% DNA Damage and the \% Tail Moment measurements from these images were calculated using the "Image J" program (a program distributed freely by the National Institute of Health of the SA, https://imagej.nih.gov/ij/download.html).

Table 1. Anaplasmosis treatment imidocarb application DNA damage results (The Comet analysis)

\begin{tabular}{l|ccc}
\hline \multicolumn{1}{c|}{ Grups } & $\mathrm{N}$ & Mean & Std. Error \\
\hline Control & 10 & 6.17784 & $0.8369342^{\mathrm{c}}$ \\
Patient & 10 & 34.2585 & $1.6235575^{\mathrm{a}}$ \\
Treatment & 10 & 15.85399 & $0.7125912^{\mathrm{b}}$ \\
\hline
\end{tabular}

$\mathrm{P}<0,0001$

Table 2. Anaplasmosis treatment imidocarb application tail moment table (The Comet analysis)

\begin{tabular}{l|ccc}
\hline \multicolumn{1}{c|}{ Grups } & $\mathrm{N}$ & Mean & Std. Error \\
\hline Control & 10 & 8.58563 & $0.3914576^{\mathrm{c}}$ \\
Patient & 10 & 38.56855 & $1.6843459^{\mathrm{a}}$ \\
Treatment & 10 & 19.38585 & $0.7243389^{\mathrm{b}}$ \\
\hline
\end{tabular}

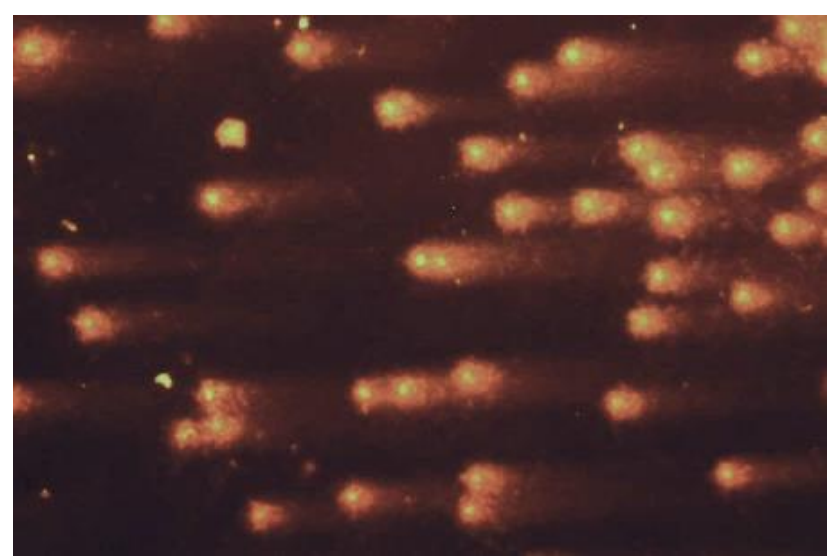

Figure 1. The image of oxidative DNA damage (comet analysis) in naturally infected sheep erythrocyte with anaplasmosis

\section{Statistical Analysis}

The data were analyzed by using ANOVA one-way at each time point to compare mean values. The significance of the difference between the groups was evaluated with the Duncan test (SPSS ${ }^{\circ}$ V.19 Evaluation Version for Windows, IBM).

\section{Results}

In this study, clinically high fever $>40$, anemia, jaundice, increased heart and respiratory rate were determined in the patient group. The smears obtained from blood samples taken from animals with clinical symptoms were stained with the Giemsa staining method and examined microscopically, Anaplasma spp. were observed in blood smears.

DNA damage after Comet analysis in blood taken from 10 sheep diagnosed with Anaplasma spp in parasitological examination. The DNA damage result after comet analysis is given in Table 1 and the tail moment table is given in Table 2.

In sick animals diagnosed with anaplasmosis, when DNA damage (Table 1) and tail moment (Table 2) are examined, values were found to be statistically significantly higher than the control group $(\mathrm{P}<0.0001)$. After imidocarb application; It was determined that DNA damage, which was found to be significantly different from the sick animals in the treatment group, decreased, but there was a significant difference compared to the control group and its value was higher $(\mathrm{P}<0.0001)$ (Table 2$)$.

\section{Conclusion}

In the case of anaplasmosis, Anaplasma agents affect erythrocytes, causing hemolysis, resulting in anemia. In recent studies, it has been reported that oxidative stress in infection caused by Anaplasma species is effective in the damage of erythrocytes and the formation of anemia (De et al., 2012; Jalali et al., 2016). In animals infected with Anaplasma, clinically haemoparasitosis, jaundice in the mucous membranes, increased heart and respiratory rates, and an average body temperature of $41.2^{\circ} \mathrm{C}$ were determined. In the laboratory examination, symptoms such as the presence of Anaplasma spp in the blood, parasitemia, normochromic and normocytic anemia, decrease in serum total protein and albumin levels, and increase in GGT and total bilirubin levels were detected (Bernardo et al., 2016).

In experimental studies, fever, constipation, diarrhea, pallor of the mucous membranes and mild icterus symptoms were detected 15-20 days after inoculation in experimentally infected lambs. In addition, although calves infected with A. marginale are more resistant to the disease compared to adult animals, they are completely susceptible to the disease when splenectomy is performed experimentally, and the clinical manifestations of the disease can be more severe (Kocan et al., 2003; Silva et al., 2014).

Esmaeilnejad et al. investigated antioxidant activity, serum mineral levels and cholinesterase activity in A. marginale-infected cows in their study and it was reported that GSH-Px, SOD, CAT, G6PD, TAC, MCF and AChE activities and serum $\mathrm{Cu}, \mathrm{Zn}, \mathrm{Mn}$, Se levels decreased significantly after developing paracythemia (Esmaeilnejad et al., 2018). 
In a study by Doyle et al., the effect of imidocarb used in the treatment of A.marginale on antioxidant, cholinergic and adenosinergic systems was examined. It has been reported that adenosine deaminase and acetylcholine esterase activities are inhibited by imidocarb application and it treats A.marginale infection by acting on antioxidant enzymes (Doyle et al., 2016).

Afifi et al. investigated the effect of imidocarb application on the immune system in Anaplasma-infected and healthy animals before and after FMDV vaccination and stated that the immune system was strengthened with imidocarb application 1 week before vaccination (Afifi et al., 2014).

In this study, DNA damage was demonstrated in naturally infected sheep with anaplasmosis by the Comet analysis. When DNA damage (Table 1) and tail moment (Table 2) were examined, the values were found to be statistically significantly higher than the control group $(\mathrm{P}<0.0001)$. After the imidocarb application, DNA damage, which was significantly different from the sick animals as the treatment group, was reduced. However, it was determined that there was a significant difference and a higher value compared to the control group $(\mathrm{P}<0.0001)$ (Table 2).

As a result, DNA damage occurs due to oxidative damage together with paracythemia in Anaplasmosis infection. In our study, it was determined that the oxidative damage formed was reduced by imidocarb administration, although statistically different, values close to the control group were reached. In future more detailed studies, the extent of DNA damage and different DNA damage markers can be examined by looking at different parameters.

\section{Conflict of Interest Statement}

Authors declare that there are no conflicts of interest.

\section{References}

Abdul Salam SF, Thowfeik FS, Merino EJ. 2016. Excessive reactive oxygen species and exotic DNA lesions as an exploitable liability. Biochemistry. 55:5341-52.

Afifi NA, Shihata M, El zorba HY, Ismail IM. 2014. Effect of Imidocarb dipropionate on the immune response to Foot and Mouth Disease vaccine in healthy and anaplasmosis-infected calves. Veterinary World 7(3): 162-167.

Aktas M, Özübek S. 2017. Outbreak of anaplasmosis associated with novel genetic variants of Anaplasma marginale in dairy cattle. Comparative Immunology, Microbiology and Infectious Diseases. 54:20-6.

Belloli C, Lai OR, Ormas P, Zizzadoro C, Sasso G, Crescenzo G. 2006. Pharmacokinetics and Mammary Elimination of Imidocarb in Sheep and Goats. J. Dairy Sci, 89:2465-2472.

Bernardo FD, Freitas FLC, Silva-Neto AF, Franciscato C. 2016. Importance of blood smear in the distinction of hemoparasites: A case report of anaplasmosis. Revista Brasileira de Higiene Sanidade Animal. 10- 2: 290-296.

Boutet-Robinet E, Trouche D, Canitrot Y. 2013. Neutral Comet Assay. Bio-protocol. 3(18): e915.

Cemeli E, Baumgartner A, Anderson D. 2009. Antioxidants and the comet assay. Mut Res Rev Mut Res. 681:51-67.

Chen J, Chen XM, Yang KD, Xia T, Xie H. 2002. Studies on DNA damage and apoptosis in rat brain induced by fluoride. Chin J Prev Med. 36:222-4.

Chiou SP, Yokoyama N, Igarashi I, Kitoh K, Takashima Y. 2012. Serum of Babesia rodhaini infected mice down regulates catalase activity of healthy erythrocytes. Exp. Parasitol. 132: 327-333.
Collins AR. 2004. The Comet Assay for DNA Damage and Repair Principles, Applications, and Limitations. Mol. Biotechnol. 26: 249-61.

De U, Dey S, Banerjee P, Sahoo M. 2012. Correlations among Anaplasma marginale parasitemia and markers of oxidative stress in crossbred calves. Tropical Animal Health and Production. 44: 385-388.

De Waal DT. 2000. Anaplasmosis control and diagnosis in South Africa. Annals of the New York Academy of Sciences. 916(1):474-83.

Değer S, Deger Y, Bicek K, Ozdal N, Gul A. 2009. Status of lipid peroxidation, antioxidants, and oxidation products of nitric oxide in equine babesiosis: status of antioxidant and oxidant in equine babesiosis. Journal of Equine Veterinary Science. 29(10): 743-747.

Dincer Y, Akcay T, Ilkova H, Alademir Z, Ozbay G. 2003. DNA damage and antioxidant defense in peripheral leukocytes of patients with type 1 diabetes mellitus. Mutat Res. 527:49-55.

Doyle RL, Fritzen A, Bottari NB, Alves MS, da Silva AD, Morsch VM. et al. 2016. Imidocarb dipropionate in the treatment of Anaplasma marginale in cattle: Effects on enzymes of the antioxidant, cholinergic, and adenosinergic systems. Microbial Pathogenesis, 97: 226 - 230.

Esmaeilnejad B, Tavassoli M, Asri-Rezaei S, Dalir Naghadeh B. 2012. Evaluation of antioxidant status and oxidative stress in sheep naturally infected with Babesia ovis. Vet Parasitol. 185: 124-130.

Esmaeilnejad B, Tavassoli M, Samiei A, Hajipour N, Baran AI, Pajuh FF. 2018. Evaluation of oxidative stress and antioxidant status, serum trace mineral levels and cholinesterases activity in cattle infected with Anaplasma marginale. Microbial Pathogenesis. 123: 402-409.

Ince S, Kozan E, Küçükkurt İ, Bacak E. 2010. The effect of levamisole and levamisole + vitamin $\mathrm{C}$ on oxidative damage in rats naturally infected with Syphacia muris. Exp Parasitol. 124(4): 448-52.

Jalali SM, Bahrami S, Rasooli A, Hasanvand S. 2016. Evaluation of oxidant/antioxidant status, trace mineral levels, and erythrocyte osmotic fragility in goats naturally infected with Anaplasma ovis. Trop Anim Health Prod. 48:1175-118.

Kocan KM, De la Fuente J, Guglielmone AA, Meléndez RD. 2003. Antigens and alternatives for control of Anaplasma marginale infection in cattle. Clinical Microbiology Reviews; 16(4):698-712.

Kubota K, Lee DH, Tsuchiya M, Young CS, Everett ET. 2005. Martinez-Mier EA, et al. Fluoride induces endoplasmic reticulum stress in ameloblasts responsible for dental enamel formation. J Biol Chem. 280:23194-202.

Kuttler KL. 1980. Pharmacotherapeutics of drugs used in treatment of anaplasmosis and babesiosis. J. Am. Vet. Med. Assoc. 176:1103-1108.

Öner AC, Dede S, Yur F, Öner A. 2020. The Effect of Vitamin C And Vitamin E on DNA Damage, Oxidatıve Status, and Some Biochemical Parameters in Rats with Experımental Fluorosis. Fluoride. 53(1-2):154-163.

Sardas S. 2005. Genotoxicity tests and their use in occupational toxicology as biomarkers. Indoor and Built Environment. 14:521-5.

Silva JB, Cabezas-Cruz A, Fonseca AH, Barbosa JD, de la Fuente J. 2014. Infection of water buffalo in Rio de Janeiro Brazil with Anaplasma marginale strains also reported in cattle. Veterinary Parasitology; 205(3-4):730-4.

Speit G, Hartmann A. 2006. The Comet Assay. In: Henderson D.S. (eds) DNA Repair Protocols. Methods in Molecular Biology ${ }^{\mathrm{TM}} .314$.

Yang J, Han R, Niu Q, Liu Z, Guan G, Liu G, Yin H. 2018. Occurrence of four Anaplasma species with veterinary and public health significance in sheep, northwestern China. Ticks and tickborne diseases; 9(1):82-5. 